doi:

\title{
Tanulási stílusok vizsgálata a Felder-Soloman teszt alapján
}

\section{Research on learning styles based on Felder-Soloman test}

\author{
Alexáné Dorogi Alexandra \\ Pedagógus, Mátészalkai Szakképzési Centrum Kállay Rudolf Szakközépiskolája, 4320 Nagykálló \\ Kossuth út 8.
}

\section{INFO}

Alexáné Dorogi Alexandra

dorogi.alexandra@gmail.com

Keywords:

Felder-Soloman test

Learning style

Learning methodology

\section{ABSTRACT}

\begin{abstract}
In my survey I try to find the answer that how secondary school students study and how teachers can use this information in their lessons when they create lesson plans. Answers of Felder-Soloman learning style questionnaire include how students receive information in the easiest way, how they systematize them and what they need to memorize them. The results are important for both students and their parents.

In results of survey we can see that the most of students are visual, concrete, active and analytic, so they are in the inductive group. A fewer of them are verbal, abstract, reflective and global, so they are in deductive group. I know the answer too that parents' educational attainment, students' daily school of, career choices and the class do not influence the studying style.
\end{abstract}

\section{Kulcsszavak:}

Felder-Soloman teszt

Tanulási stílus

Tanulási módszertan
Absztrakt: A tanulmányban arra a kérdésre kerestem a választ, hogy a középiskolai diákokra milyen tanulási stílus a jellemző, és a kapott információkat hogyan használhatja fel a pedagógus a tanítási módszerek kiválasztásakor és ennek alapján hogyan építse fel az órát. A Felder-Soloman Tanulási stílus teszt arra ad választ, hogy a tanulók milyen módon fogadják be legkönnyebben az információt, hogyan rendezik azokat, mire van szükségük az elraktározásához. $\mathrm{Az}$ eredmények a diákoknak és a szülőknek is egyaránt fontosak.

A vizsgálatból kiderült, hogy a tanulók nagy része a vizuális, a konkrét, az aktív, az analitikus, így az induktív csoportba tartozik. A kitöltők kisebb része tartozik a verbá- 
lis, az absztrakt, a reflektív, a globális és így a deduktív csoportba. Arra is sikerült választ kapni, hogy a szülök iskolai végzettsége, a tanuló napi iskolába járása, a szakmaválasztás és a tanuló évfolyama nem befolyásolja a tanulási stílust.

Ez a tanulmány a Tudományos Diákköri Konferencia keretében jött létre.

\section{Bevezetés}

„Az iskola arra való, hogy az ember megtanuljon tanulni, hogy felébredjen tudásvágya, megismerje a jól végzett munka örömét, megizlelje az alkotás izgalmát, és megtalálja a munkát, amit szeretni fog. "

/Szent-Györgyi Albert/

A mai információs társadalom és a $Z$ generációs fiatalok szokásai, mindennapi tevékenységük szinte teljesen megváltozott. McCrindle (2012) szerint ök már a teljesen digitalizált korszakban nevelkednek, így jellemző rájuk a 24/7 online-lét, ami azt jelenti, hogy 24 órában elérhetőek a hét minden napján. A digitális világ, a mobilitás nagyban befolyásolja a tanulásukat is. McCrindle szerint a vizualitás jellemzi őket, azaz, hogy az új ismereteket, információkat képileg jegyzik meg jobban.

Pedagógusként a tananyaggal mindig új információt, új ismeretet adunk át a tanulóknak. Ezt a pedagógusoknak úgy kell ismertetnie, hogy a diák is megértse, és minél jobban el tudja sajátítani. Ezért is kezdtem keresgélni hatékony módszereket erre a helyzetre, hiszen a változást a pedagógusnak is nyomon kell követnie, hogy az adott generációnak mi lehet a legsikeresebb megoldás a tananyag elsajátításában.

A diákok számára fontos azoknak a módszernek a megismerése, amivel a leghatékonyabban tudnak tanulni. Így érhetnek el sikereket. Ha valaki már az elején elveszíti a tanulási motivációt, igen nehéz visszatalálnia a tanuláshoz. Ha nem sajátítja el, hogyan is kell tanulni, akkor céltalanná válik a tanórán, valamint otthon sem fog leülni, házi feladatot készíteni, illetve a tanyagot elővenni és megtanulni.

Tanulmányomban a tanulási stílusokat mutatom be a Felder-Soloman teszt segítségével. A kérdőívet 464 nyíregyházi középiskolai tanulóval sikerült kitöltetni.

Úgy gondolom, igen hasznos, ha tanulóként tudjuk, hogy melyik csoportba is tartozunk, hiszen a tananyagot ennek megfelelően tudjuk elsajátítani. Ha pedig tanárként dolgozunk, akkor fontos annak felismerése, hogy a diákok mely csoportba tartoznak. Ha ezt figyelembe vesszük az órák tervezésénél és levezetésénél, akkor sokkal hatékonyabb, eredményesebb lesz az elsajátítandó anyag visszacsatolása. A tanulók ezáltal pozitív élményekhez jutnak, teljesítményük nő.

A mai világban nagyon fontos felismerés lenne, hogy a szülö is megtudja, miért is teljesít alul vagy nagyon jól egy-egy tárgyból a gyermeke. A felmérés eredménye számukra is mérvadó lehet. Ha tudnák, hogy hogyan segíthetnének könnyebben tanulni otthon a gyermeküknek, akkor eredményesebb, sikeresebb tanulás lenne az eredménye. 
Ha ez a három tényező - gyerek, szülő, iskola - felismeri a diák tanulási stílusát, sokkal jobb teljesítményre lesz képes a tanuló, jobb átlagot tud hozni az iskola, valamint a szülö is boldog lehet, hogy a gyereke megtanulta, hogyan is kell tanulnia.

A tanulási stílus nem felismerése komoly károkat okozhat. Ha egy diák nem lesz motivált, olyan képességü tanulókat veszíthetünk el, akik egy másik tárgyból esetleg kitünő eredménnyel szerepelhetnének. Hiszen mindenkinek megvannak az erősségei, csak meg kell találni azt. Ehhez kell a három tényezőnek összefognia és a gyereknek akarni tanulni, hogy sikeres ember váljék belöle, és megtalálja magának azt a szakmát, ami a szívéhez közel áll. Ezen kívül az iskola is meg tudná tartani a gyerekeket. Sok iskolából lehet azt hallani, hogy nagy a lemorzsolódás. Mindenki küzd a tanulókért és azért, hogy bent tartsák őket az oktatásban. De ez ellen az iskola is úgy tudna tenni, ha megfelelö tanulási körülményeket biztosítana a diákok számára.

Egyes iskolákban kevés segítség áll a tanárok rendelkezésére. Sok helyen nincs projektor, amellyel színesebbé lehetne tenni az órát, melynek segítségével gyakorlatias videókat és játékos feladatokat tudnánk vetíteni, hogy a modern technológiát is bevonjuk a gyerekek oktatásába. Vagy a táblára ne csak fehér krétával tudjunk írni/rajzolni, hiszen a színek is fontos szerepet játszhatnak egy-egy tananyag megértésénél és elsajátításánál.

A Felder-Soloman teszt kiválóan alkalmas arra, hogy megismerjük egy egyén vagy egy csoport tanulási stílusát. Ezáltal a pedagógus felépítheti a tanórát, beszerezheti a szükséges eszközöket.

A tanulmány első részében azzal foglalkozom, hogy bemutatom a FelderSoloman tesztet, hogy melyik dimenzió miröl szól, majd rátérek a saját kutatásomra. A kérdőíves felmérés eredményeinek ismertetése után levonom a következtetéseket és javaslatokat is teszek, hogy merre lehetne kibővíteni a kutatást.

\section{Elméleti háttér}

\section{A tanulás megközelítése}

A tanulás nem velünk született képesség. Gyakorlás útján lehet fejleszteni. „A tanulás során tartós tudást szerzünk, az új információt hosszú távú memóriánkban raktározzuk el. A tanulás továbbá valamiképpen fejlödés: csak akkor beszélünk tanulásról, ha hatása elösegiti, hatékonyabbá teszi a környezethez való alkalmazkodásunkat. A tanulás az elmében bekövetkezö adaptív változás." (KNAUSZ, 2001).

A tanuláshoz valamilyen motiváció szükséges. Meg kell határozni, hogy mi célból is tanulunk (motiváció törvény). Az eredményes tanuláshoz szükséges a folyamatos gyakorlás (frekvencia törvény). A tanulás során az a hatás erősödik, amely megnyugtató állapotba helyez, de amelyet büntetés is kísérhet (effektus törvény). Ezek a tanulási folyamatok, tapasztalatok átvihetők, felhasználhatók minden új tanulásnál (transzfer törvény) (DINYÁNÉ, 2013).

Úgy gondolom, a mai világban nagyon nehéz megtalálni a diákoknak a motivációt. El kell érni, hogy sikernek könyvelje el a tanulást, tehát kell lennie sikerélménynek. 


\section{Tanulási stílusok, módszerek}

Minden egyes ember sajátos tulajdonságokkal rendelkezik, melyek biológiai, fejlödési és szocializációs folyamatok által meghatározottak. Az egyéni preferenciák meglévő készlete befolyásolja gondolkodásunkat, viselkedésünket, a tanuláshoz való viszonyulásunkat és az ismeretek feldolgozásának módját is. Balogh (1993) megfogalmazásában a tanuló önálló tanulásában megmutatkozó stílusjegyeket nevezzük tanulási stílusnak, míg Mező (2002) szerint az egyén által előnyben részesített külső és belső tanulási feltételeket jelenti.

A tanulási stílus nem az intelligencia mércéje, hanem azoknak a belső energiáknak az összessége, amelyeket az egyén a tanulás során használ. Nem más, mint az információ befogadásának és az új ismeretek feldolgozásának módja. A tanulási nehézségekkel küzdők számára pedig kulcsfontosságú is lehet, hiszen ez lehet a megoldás arra, hogy sikeresen tanuljanak (BERNÁTH, KOLLÁR, NÉMETH, 2015). Ezek a tanulási stílusok stratégiák is lehetnek, hiszen különféle módszerekkel tudunk tanulni. Ez egyénenként eltér és változik, hogy kinek mi jelent segítséget.

Oroszlány (2004) szerint a tanulásra először egy alkalmas állapotot kell létrehozni. Ezt nagyon nehéz elérni, mert mindennek rendben kell lennie ahhoz, hogy az ember tökéletesen tudjon a munkájára, a tanuló pedig a tanulásra koncentrálni. Szinte már majdnem lehetetlen is, annyi dologra kellene koncentrálni. Példának okáért a teljesség igénye nélkül, a következő néhány hétköznapi dolgot emelném ki a szerző gondolatából: figyelni kell a testi-lelki egyensúlyra, a mozgásra, ugyanakkor eleget kell játszani, időben kell a televíziót kikapcsolni és időben aludni, hogy kipihenten kelljen fel az ember. Összesen 18 dolgot fejt ki bőven, hogy mi mindenre kell odafigyelni, majd ezek után jöhet a tanulás.

A tanulást már általános iskolás korban el kell kezdeni, rá kell vezetni a gyermeket arra, hogy hogyan is kell tanulni. Nem szabad elvenni a gyerek kedvét a tanulástól, mert utána már nehezen fog visszatalálni. Ha a gyermek kérdez, akkor feleljünk rá, vagy próbáljunk meg neki segítséget adni, hogy hol tud utána nézni, ha már elég érett ahhoz, hogy például a számítógépen az internet segítségével kereshet. Ezzel azt is fejleszteni tudjuk, hogy nemcsak játékra tudja használni a számítógépét. Sok hasznos dolgot fel tud fedezni, ami a saját korosztályának megfelelö.

Oroszlány (1997) adott tanácsot ahhoz, hogy mivel is kezdjünk neki a tanulásnak. Az első és legfontosabb az iskolai tanulás. Itt már sok mindent megjegyezhet a tanuló. Azt kell elérnie a pedagógusnak, hogy fent tudja tartani a figyelmet órán. Amennyiben ez lankadna, vannak tanulást segítő módszerek, mint például a nyújtózkodás, amivel kicsit fel lehet frissíteni mindenkit, felgyorsul a keringés és az óra zökkenömentesen mehet tovább. Ez körülbelül 2-3 percet vesz igénybe, mégis a tanulók utána megint jobban tudnak koncentrálni.

Tehát fontos, hogy a tanár felépítse az órát. Azokat a kérdéseket lehet feltenni, hogy mit tegyen, hogyan tegyen, és miért tegyen. Az első a tudatosságra épül, a második a készséget fejleszti, az utolsó pedig motivál. Az egész pedig szokássá válik (GINNIS, 2007).

\section{Felder-Soloman teszt}

A tesztet két tudós, Richard M. Felder és Barbara A. Soloman állították össze 2005ben. A Felder-Soloman teszt egy csoport tanulási stílusát vizsgálja. 44 kérdésből álló 
kérdőívet kell kitölteni. Az egyéneket és magát a csoportot is 5 különböző dimenzióban vizsgáljuk meg, amelyek a következők:

- az információ érzékelése,

- az információ felvétele,

- az információ feldolgozása,

- az információ megértése,

- az információ közötti következtetések.

A paraméterek feldolgozása után képesek vagyunk a vizsgált csoporttal kapcsolatban információk közötti következtetések levonása alapján is megmondani, hogy az adott csoport hová is sorolható.

Makó (2015) szerint „, a tanulási stílus négy tényező kombinációjából tevődik össze:

- Milyen módon fogadjuk be legkönnyebben az információt - föleg vizuális, auditív, kinesztetikus vagy taktilis tanulók vagyunk; vajon legjobban a látás, hallás, mozgás vagy érintés útján tanulunk?

- Hogyan rendszerezzük és dolgozzukfel az információt - vajon túlnyomórészt jobb féltekés vagy bal féltekés, analitikus vagy globális módon?

- Milyen feltételekre van szükségünk, amelyek segitenek az információ felvételében és elraktározásában - érzelmi, társas, fizikai és környezeti?

- Miként hívjuk elö az információt - ami teljesen különbözhet attól, ahogyan felvettük vagy elraktároztuk."

Magyarországon kevés cikket, kutatást lehet találni. 2014-2015-ben Vörösmarty Gyöngyi készített egy publikációt, aki a Budapesti Corvinus Egyetem három képzésén 198 hallgatót kérdezett meg, az átlagéletkoruk 29-35 között volt a szakokon. Mindhárom szaknál hasonló eredményt kapott a dimenziók között, ugyanis a hallgatók a szenzoros, a vizuális, az aktív, valamint a szekvenciális csoportba tartoznak.

A másik kutatás 2016-ban történt, szintén a Budapesti Corvinus Egyetemen, amelyet Dr. Bodnár Éva és Dr. Sass Judit végzett. A vizsgált minta 291 fó, átlagéletkoruk 19,52. Az eredmény itt is ugyanazt mutatta, tehát a kitöltők az érzékelő, az aktív, a vizuális, valamint a szekvenciális csoportba tartoznak.

\section{Információ érzékelése (vizuális-verbális)}

Az információkat vizuálisan, vagy verbálisan érzékeljük. A vizuális típusú diákok számára fontosak a képek, animációk, a videók. Lényeges a tananyag elrendezése és felépítése, mivel a memorizálás és a felidézés is képileg történik. A vizuális ember az illusztrációkra kattint, felnagyítja azokat, kedveli a színes betűket és kiemeléseket. Látva, megfigyelve tanulnak, és kifejezetten jól tudnak emlékezni vizuális részletekre. A tanár használhat ilyenkor projektort, színes kártyákat vagy különböző képeket.

A verbális beállítottságú ember számára fontosak a hanganyagok, könnyebben tanul akár hangfelvételröl, sokszor felmondja a tananyagot. A vizuális típussal ellentétben a videókból a hangokra emlékszik, nem pedig a képanyagra (BALOGH, 1995). Játékos módszer lehet ezen tanulók számára az, ha például a tananyagot hangfájlként küldjük át nekik. Ők abból próbálják meg kiszürni, kijegyzetelni a lényeget. 


\section{Információ felvétele (konkrét-absztrakt)}

Az információ felvétele történhet konkrét és absztrakt módon. A konkrét típusú embereket a világ konkrét jelenségei érdeklik, sokszor építenek saját tapasztalatra, jól teljesítenek a rutinfeladatokban, viszont hiányzik belőlük a fantázia, a kreativitás. Aprólékosak, a komplex feladatok sokszor kihívást jelentenek számukra. A mai Z generációs gyerekek, azaz a mai fiatalok ritkán olvasnak. Egy könyv, ami csak betükből áll igazán kihívás számukra. Képzelőerő kell ahhoz, hogy a történetet fejben tudják tartani és a leírás alapján például a tájat, a személyt el tudják képzelni. Talán ezért sem szívesen olvasnak a tanulók. A tanárnak segítségére lehet ilyenkor, ha a feladattípusokat begyakoroltatja és ezen nem változtatva kéri számon.

Az absztrakt, intuitív emberek sokszor látják az összefüggéseket, sokszor a megérzéseikre hagyatkoznak. Nagy képzelőerővel rendelkeznek, viszont nem szeretik az aprólékos dolgokat, és rossz megfigyelők (DINYÁNÉ, 2013). Nekik az irodalom és a humán típusú tárgyak fognak jobban menni, melyeknél néha a mondat mögé kell látni, el kell vonatkoztatni a dolgokról. Tehát itt is fontos, hogy a gyerek megtalálja magát, hogy melyik tárgyban lesz sikere.

\section{Információ feldolgozása (aktív-reflektív)}

Az információt feldolgozhatjuk aktívan vagy reflektíven. Az aktív csoportba tartozók tevékenyek, tettre készek, a pillanatért élnek. Adjunk nekik feladatokat, hogy nézzék meg az interneten, abból többet fognak tanulni, mert számukra fontos lehet az, hogy kutassanak bizonyos dolgok után. Meg kell mozgatni őket, nyitottak, és az új élményeket keresik, így tehát nem is szívesen tanulnak könyvböl, vagy egyszerü e- tananyagból.

A reflektíven feldolgozók folyamatosan megfigyelik a tananyagot, és az új ismereteket a saját rendszerükbe próbálják beilleszteni. A tökéletesre törekednek, az elmélet érdekli őket, a megvalósítás nem. Jól vitatkoznak, és nem toleránsak (KATHYNÉ, 2013). A folyamatos bővítés a lényeg: a korábbi ismereteket újítsuk és mindig egészítsük ki valamilyen új ismerettel, új információval, mert ők így fogják beépíteni a tanulmányaikba.

\section{Információ megértése (analitikus-globális)}

Az információk megértése történhet analitikusan vagy globálisan. Aki analitikusan gondolkodik, egyszerre egy dolgot képes megfigyelni. Tanulása szabályozott, a jól elkülönülö, kicsi tananyagelemeket preferálja. Lépésröl lépésre halad. Saját jegyzetet készít. A részekből építik fel az egészet és a feladatmegoldásban logikusak. Ezen tanulók nyelvi és szóbeli kifejezősége általában igen jó, és a tényekből való építkezés, nézetkialakítás, fogalomalkotás során töprengő, elgondolkodó magatartást mutatnak.

A globálisan gondolkodó nagy összefüggő rendszert lát, melyben az apró elemekre nem figyel. Az adatok, tények nem érdeklik, egy fejezetet egészként kezel. Sok időt tölt a tanagyaggal, a kiegészítő anyagokat is megnézi. Ezen tanulók müvészi hajlamúak, kreatívak, intuitívak, egyszerre több projekten képesek dolgozni, nincs időérzékük, szükségük van arra, hogy tevékenységük célját megbeszéljék, és/vagy egy konkrét példán lássák azt (KATHYNÉ, 2013). Hagyjunk nekik elég időt, mert ha rájönnek a feladat megoldására, akkor utána az olyan feladatokkal meg fognak tudni birkózni, meg fogják tudni oldani. 


\section{Információk közötti következtetések (induktív-deduktív)}

A következtetés igazából az a gondolkodásmód, ahogy logikus eredményekre jutunk. Ha megvizsgáljuk az eddigi eredményeket, és összeadjuk a vizuális, konkrét, aktív és analitikus számokat, akkor megkapjuk az induktív számot. Ha pedig a verbális, absztrakt, reflektív és globális eredményeket adjuk össze, akkor megkapjuk a deduktív számot. Attól függően dől el, hogy melyik lesz többségben, hogy az adott illető induktív vagy deduktív.
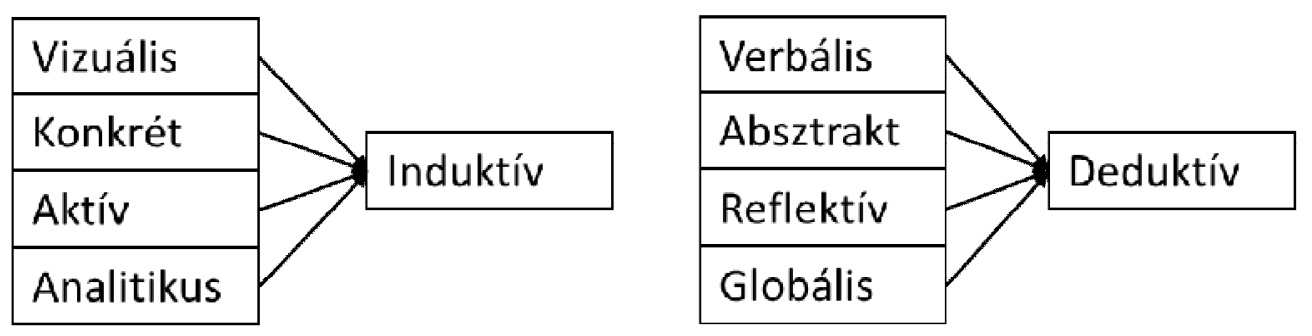

Forrás: Saját szerkesztés

1. ábra: Információk közötti következtetések

Az induktív következtetés esetén az egyes eredményekből, adatokból következtetünk az általános törvényszerüségekre. Ezt a módszert fogalmak, definíciók megtanulására használhatjuk.

A deduktív következtetés során az általános tételből következtetünk az egyedire. Ilyenkor a tanulók korábbi ismereteire alapozunk (DINYÁNÉ, 2013).

\section{Anyag és módszer}

„A tanulmányi követelmények csak egy bizonyos pontig bizonyulnak elegendőnek. Az elhivatottságod, a lelkesedésed és mindenekfelett a személyiséged és a jellemed fog majd hozzásegíteni ahhoz, hogy sikerrel járj. "

/Tim Peakel

2018. májusában egy kérdőíves felmérést készítettem több nyíregyházi középiskola tanulóival, hogy megtudjam, milyen tanulási stílusba tartoznak. A helyi Szakképzési Centrum, valamint a helyi Tankerület vezetőinek kértem a segítségét, hogy jutassák el a tagintézményeikbe a kérdöívet, és informatika óra keretén belül töltsék is ki minél többen.

A fő vizsgálati kérdésem a Felder-Soloman teszt alapján az volt, hogy megtudjam, a tanulók mely csoportba tartoznak. A kérdőívet 464 tanuló töltötte ki a nyíregyházi középiskolákban. Minden kérdést megvizsgálva, először is szeretném megtudni a nemenkénti eloszlást is, hogy milyen arányban töltötték ki.

A válaszadók 36\%-a férfi, 64\%-a nő. A kérdőívet kitöltők átlagéletkora 17 év. A 2011. évi KSH (Központi Statisztikai Hivatal) népszámlálási adatok szerint a férfi- 
nő arány ennél a korosztálynál 51\% férfi és 49\% nő Szabolcs-Szatmár-Bereg megyében.

A válaszadók három csoportba sorolhatók: gimnázium, szakgimnázium és szakközépiskola. Ennek megoszlását a 2. ábrában mutatja.

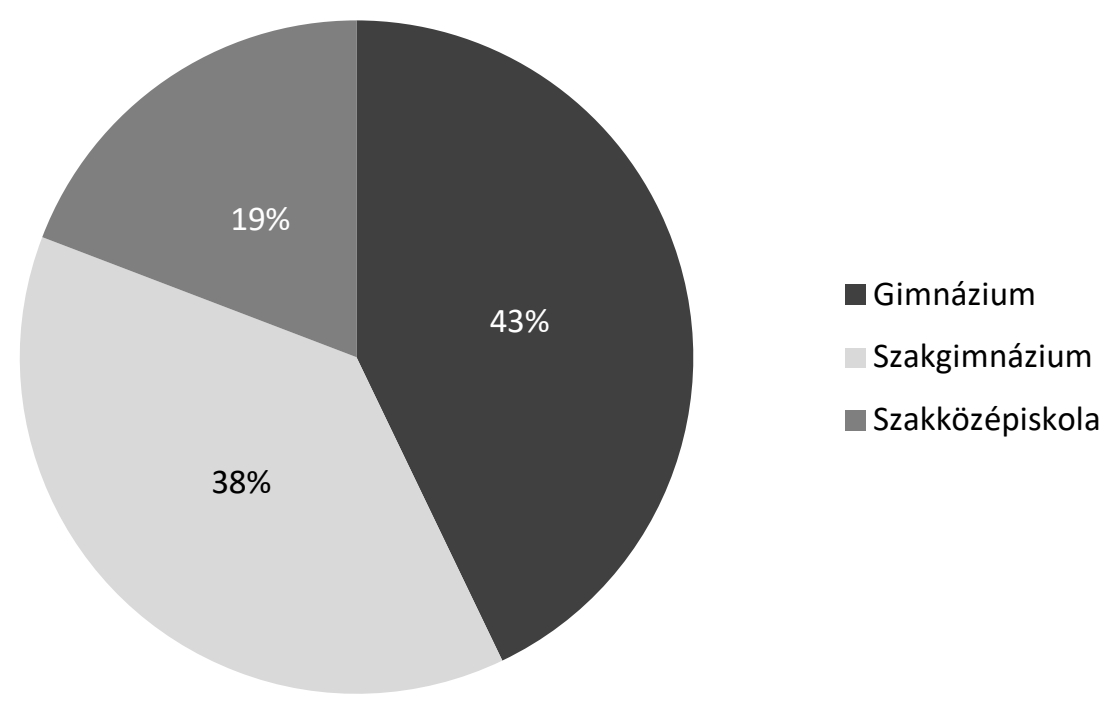

Forrás: Saját szerkesztés

2. ábra: A válaszadók eloszlása középiskolai típusonként

A válaszadók nagyobb része gimnáziumba jár, ami 43\%, a szakgimnáziumi 38\%. A legkevesebben a szakközépiskolai részből töltötték ki a kérdőívet (19\%).

Azt, hogy egyes iskolákban, milyen volt a nemek eloszlása, az 1. táblázatban mutatom be.

\begin{tabular}{|l|c|c|}
\hline & Fiú & Lány \\
\hline Gimnázium & $32,7 \%$ & $67,3 \%$ \\
\hline Szakgimnázium & $30,1 \%$ & $69,9 \%$ \\
\hline Szakközépiskola & $53,9 \%$ & $46,1 \%$ \\
\hline
\end{tabular}

Forrás: Saját szerkesztés

1. táblázat: Nemenkénti megoszlás középiskolai típusonként

A gimnáziumi, valamint a szakgimnáziumi osztályban közel egyharmadkétharmad arányban van a fiú-lány arány, míg a szakközépiskolába picivel több, mint a fele fiú volt a kitöltőknél.

A válaszadók átlagétkora 17,1. Ennek iskolai megoszlását az 2. táblázatban szemléltetem. 


\begin{tabular}{|l|c|}
\hline Gimnázium & 16,7 \\
\hline Szakgimnázium & 18 \\
\hline Szakközépiskola & 16,1 \\
\hline
\end{tabular}

Forrás: Saját szerkesztés

2. táblázat: Átlagéletkor megoszlása

Mint láthatjuk, a legmagasabb életkor a szakgimnáziumi részen van, ami 18 év. Úgy gondolom, ez azért lehet, mert a szakgimnázium 5 éves képzés, míg a gimnázium 4 éves, ahol az átlagéletkor már csak a 16,7 év. Legkevesebb a szakközépiskola, ahol jelenleg 3 éves képzés folyik, itt az átlagéletkor 16,1 év.

\section{Eredmények}

A vizsgálat során arra voltam kíváncsi, hogy a mintába került diákok milyen csoportba tartoznak a Felder-Soloman teszt alapján. Hipotézisként megfogalmaztam, hogy a válaszadók nagy része a vizuális csoportba tartozik.

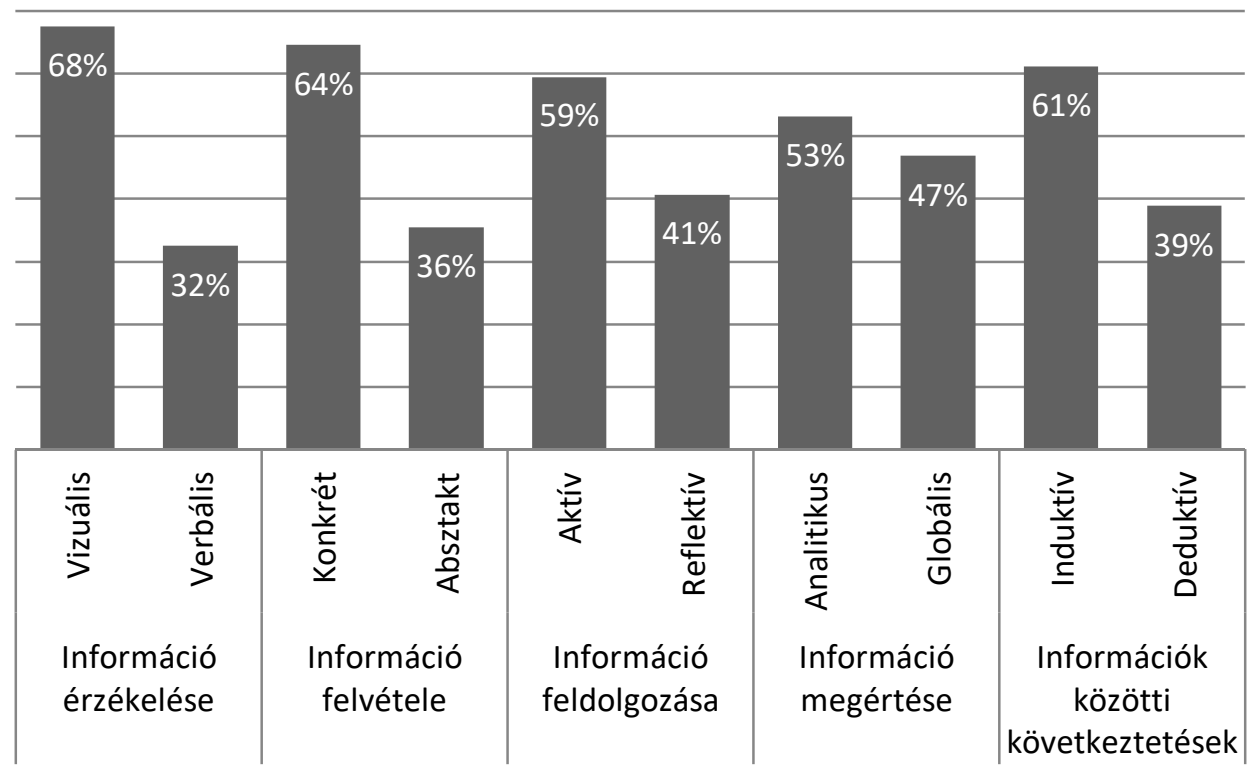

Forrás: saját szerkesztés

3. ábra: Az információ

A diagramból kiderül, hogy a válaszadók nagyobb része, $68 \%$-a a vizuális csoportba tartozik, míg 32\%-a a verbális csoportba. Ebből kiderül, az információt látással szer- 
zik, fontos nekik a kép megjelenítés a tanórán. Jobban tanulnak színek, képek alapján. Ennél a korosztálynál mindenképp fontos lenne a projektorok használatát, hiszen ha a diák látja, könnyebben feldolgozza az új információt. A pedagógusnak a projektoron kívül még segítségére lehet egy-egy videó által szemlélteni a tananyagot. Ezáltal a vizuális tanuló kép alapján rögzíti az elsajátítani való anyagot, ugyanakkor hallja is, ami a verbális csoportnak kedvez. A csoportok általában nem homogének. A verbális csoportba a kitöltök 32\%-a tartozik: hallás után könnyedén tanulja meg a tananyagot, így neki segítségére lehet egy diktafon, ahova felmondhatja saját magának a megtanulandó szöveget és ezt visszahallgatva sikeresen fog teljesíteni. Minden évfolyamban jellemző volt, hogy a diákok a vizuális szemléltetést részesítik előnyben. Sok esetben otthon nincs lehetőség a modern informatikai eszközök használatára, az anyagi lehetőségek sok helyen korlátozottak.

A következőkben az információ felvételét vizsgálom a csoportnál: konkrét vagy absztrakt típusba tartoznak. A válaszadók 64\%-a a konkrét típusba tartozik. Az adatokat szívesen figyelik meg, szeretik az aprólékos munkát. A rutinfeladatokban jól teljesítenek, tehát ha begyakorlunk egy adott típust, akkor valószínúleg a sémája alapján meg fogja tudni oldani a hasonló feladatokat. De a hátránya, hogy hiányzik belölük a fantázia. Ez összefüggésben áll azzal, hogy a mai tanulók keveset és ritkán olvasnak. A könyvekhez nagy képzelőerő kell. Át kell látni a történetet az elejétől a végéig, emlékezni kell az egészre. Így ehhez szorosan kapcsolódik az is, hogy a komplex feladatok kihívást jelentenek számukra. Egy bonyolult, összetettebb számítást már nem fognak tudni elvégezni, tehát kis részekre kell osztani nekik, hogy megértsék. Az absztrakt csoportba a válaszadók 36\%-a tartozik. Ök szeretnek olvasni, mert van képzelő erejük, viszont nem szeretik az aprólékos munkát, elvesznek benne. Ezzel ellentétben az összefüggéseket a feladatoknál hamar és gyorsan átlátják.

A harmadik dimenzió az volt, hogy az információt hogyan dolgozzák fel a megkérdezettek: aktívan, vagy reflektíven. A válaszadók nagyobb része, 59\%-a tartozik az aktív csoportba. Így ha a csoport összetétele ezt mutatja, a tanárnak olyan feladatot kell adni a diákoknak, ami úgy készteti őket tanulásra, olvasásra, hogy ne csak a könyvből, hanem valamilyen új e-tananyagból történjen. Ök nem fognak a tökéletesre törekedni, hanem csak épp annyit szeretnének elvégezni a munkából, ami ki van osztva. Nem fognak belefektetni több energiát a munkába. A mai fiatalok már a $Z$ generációhoz tartoznak, így a felgyorsult világ azt eredményezi, hogy nem kell minden fejben tartani, gyorsan elökapja az okostelefont és megnézi az adott kérdésre a választ. Kevesebben, azaz $41 \%$ van a reflektív csoportban, akiknek a lényeg a lépésről lépésre bővítés. Az új ismereteiket beépítik a már eddig megszerzett tudásukba. Mindig a lehető legjobbra törekednek.

A következő dimenzió az, hogy az információ megértése analitikus vagy globális a vizsgált diákok körében. A vizsgálat eredménye, hogy közel 50-50\%-ban oszlik meg a kitöltők válasza. Az analitikus csoportba tartozók (53\%) egyszerre csak egy dologra tudnak koncentrálni. Tehát ne adjunk egyszerre több feladatot nekik. A sorrend kialakításában is segítséget kell nyújtanunk. A globális csoport (47\%) először egy átfogó képet szeretne kapni. Tehát az egésztől kezdjük, mert az apró részletekben el fognak veszni és nem is nagyon fogja őket érdekelni. Ebbe a csoportba tartozók sokszor elolvassák a kiegészítő anyagokat. 
A következő vizsgálat az, hogy a válaszadók összességében az információk közötti következtetéseket hogyan vonják le. Ez történhet induktívan vagy deduktívan. Mint láthatjuk, az induktív csoportba a kitöltők 61\%-a tartozik. Ez azt jelenti, hogy a mai fiatalok szeretik a tényeket, szívesen figyelnek meg, tehát a definíciókat, fogalmakat könnyebben tanulják meg. A válaszadók 39\%-a a deduktív csoporthoz sorolható, akik gyakorlati módon próbálják meg beilleszteni az új tananyagot a már meglévő tudásukhoz. A korábbi ismereteikre fognak hagyatkozni. Náluk a tananyag folyamatos bővítése a cél.

A Felder-Soloman teszt segítségével megnéztem, hogy a válaszadók mely csoportba tartoznak inkább. Ezek után olyan összefüggéseket vizsgáltam, amelyek már a válaszadók környezeti, társadalmi hátterében nézi az induktív-deduktív megoszlást.

Ennek kapcsán elsőként azt vizsgálom, hogy a nemenként van-e különbség, hogy induktív vagy deduktív csoportba tartoznak-e. Feltételezésem az, hogy lényeges különbség nincs. Ennek megoszlását a 4. ábrában szemléltetem.

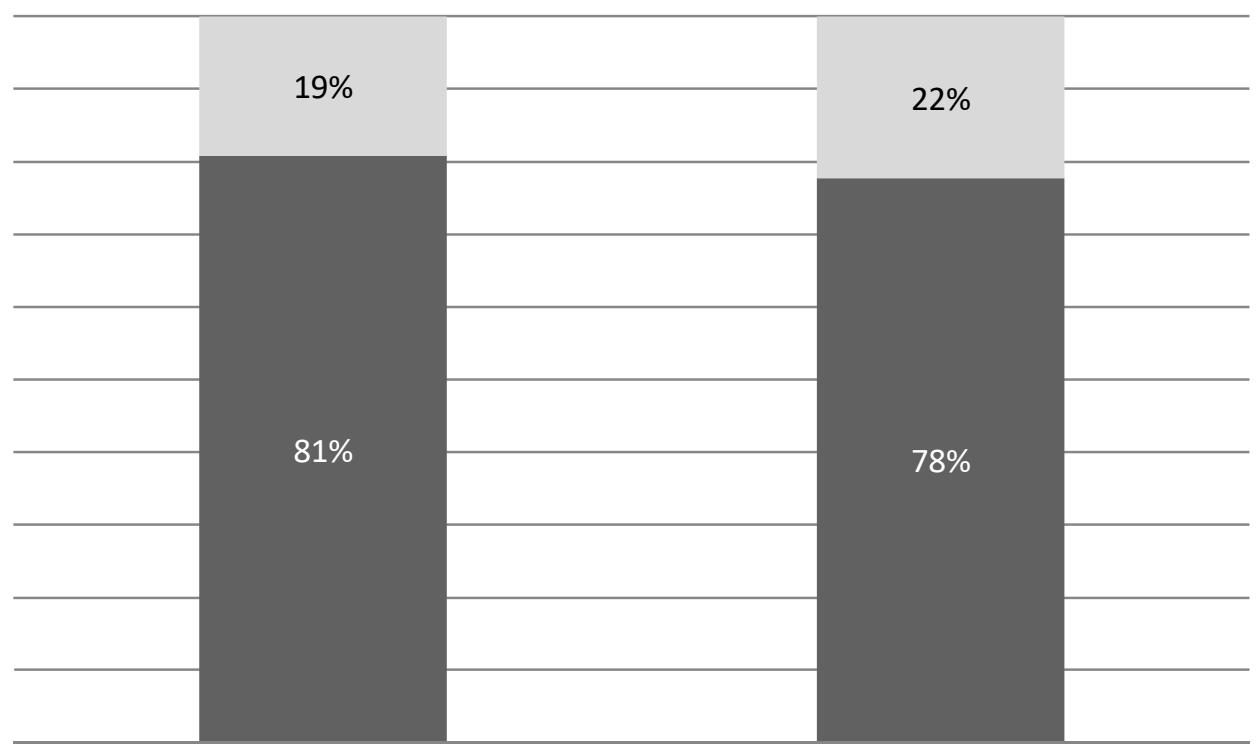

nő

férfi

induktív deduktív

Forrás: Saját szerkesztés

4. ábra: Nemenkénti induktív-deduktív eloszlás

Mint láthatjuk, a feltételezésem igaz volt, hisz nincs lényeges különbség az információk közötti következtetés illetően, hiszen a nőknél 81\%-a induktív, míg a férfiaknál $78 \%$. A deduktív arány a nő-férfi esetében pedig 19-22\%.

Következőként azt vizsgáltam, hogy a szülők végzettsége befolyásolja-e a tanuló induktív-deduktív beállítottságát. 


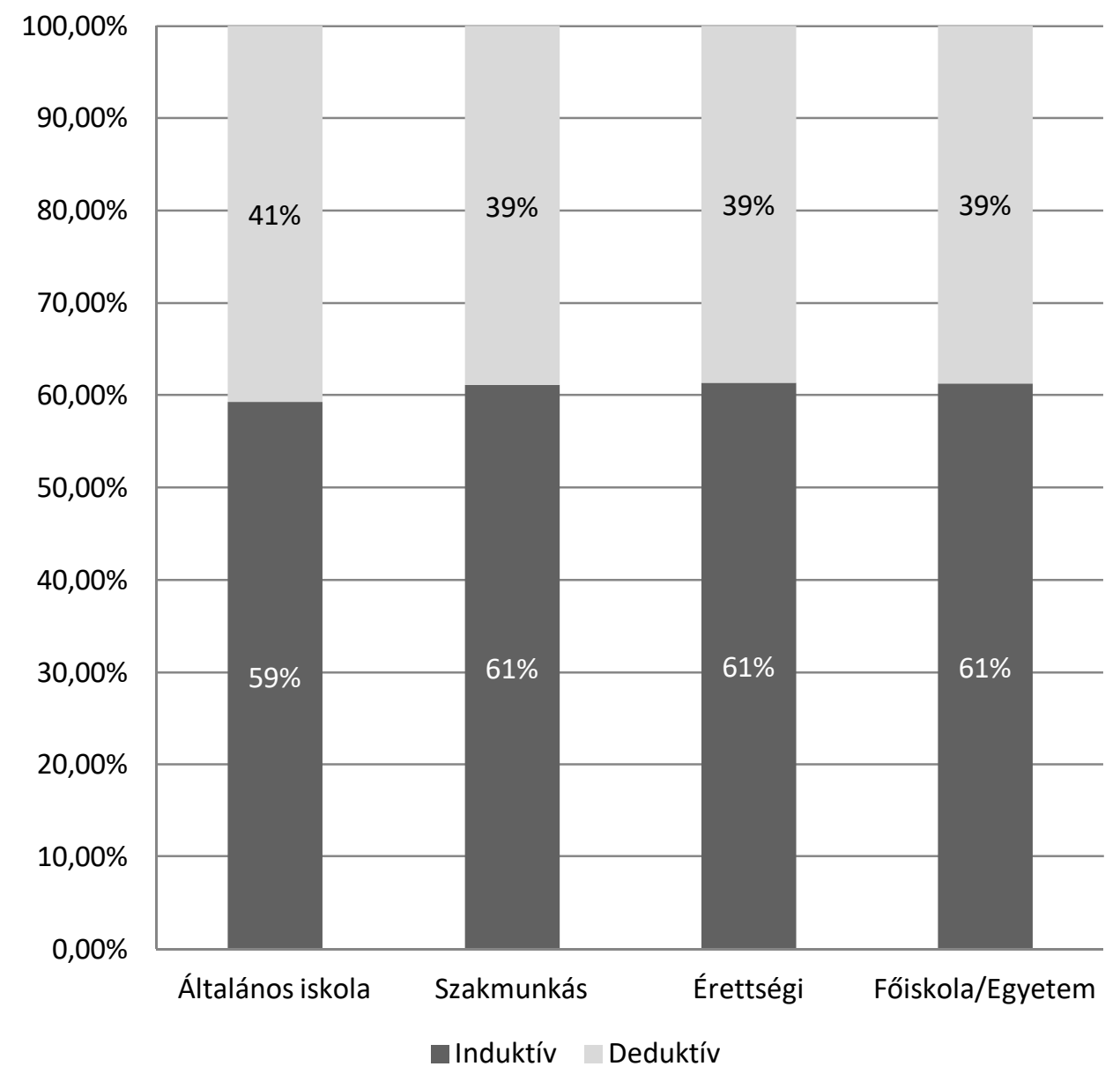

Forrás: Saját szerkesztés

5. ábra: A szülök végzettsége szerinti következtetés

Mint láthatjuk, hasonló arányban vannak az induktív és deduktív csoportba tartozók az alacsonyabb és a magasabb végzettségü szülők gyerekeinél. Az általános iskolai végzettségü szülők gyerekeinél az induktív csoportba 59\% tartozik, míg a deduktív csoportba $41 \%$. A szakmunkás végzettséggel rendelkező szülők gyerekeinél $61 \%$ tartozik az induktív csoportba és 39\% a deduktív csoportba. Az érettségivel rendelkező szülöknél kicsit magasabb a megoszlás, itt az induktív-deduktív arány $61 \%$ és $39 \%$. A főiskola/egyetem végzettségü szülők gyerekeinél szinte hasonló a helyzet, mint az előző csoportnál, itt 61\%-a van az induktív csoportba és 39\% a deduktív csoportba.

A következő vizsgálatnál a diákokat különböző szakirányokra osztottam be: építőipar, kereskedelem-marketing, müvészet, nyelv és turizmus-vendéglátás, valamint külön kategória a gimnázium, hiszen ez nem szakirány. Ennek eredményét a 6 . ábrában mutatom be. 


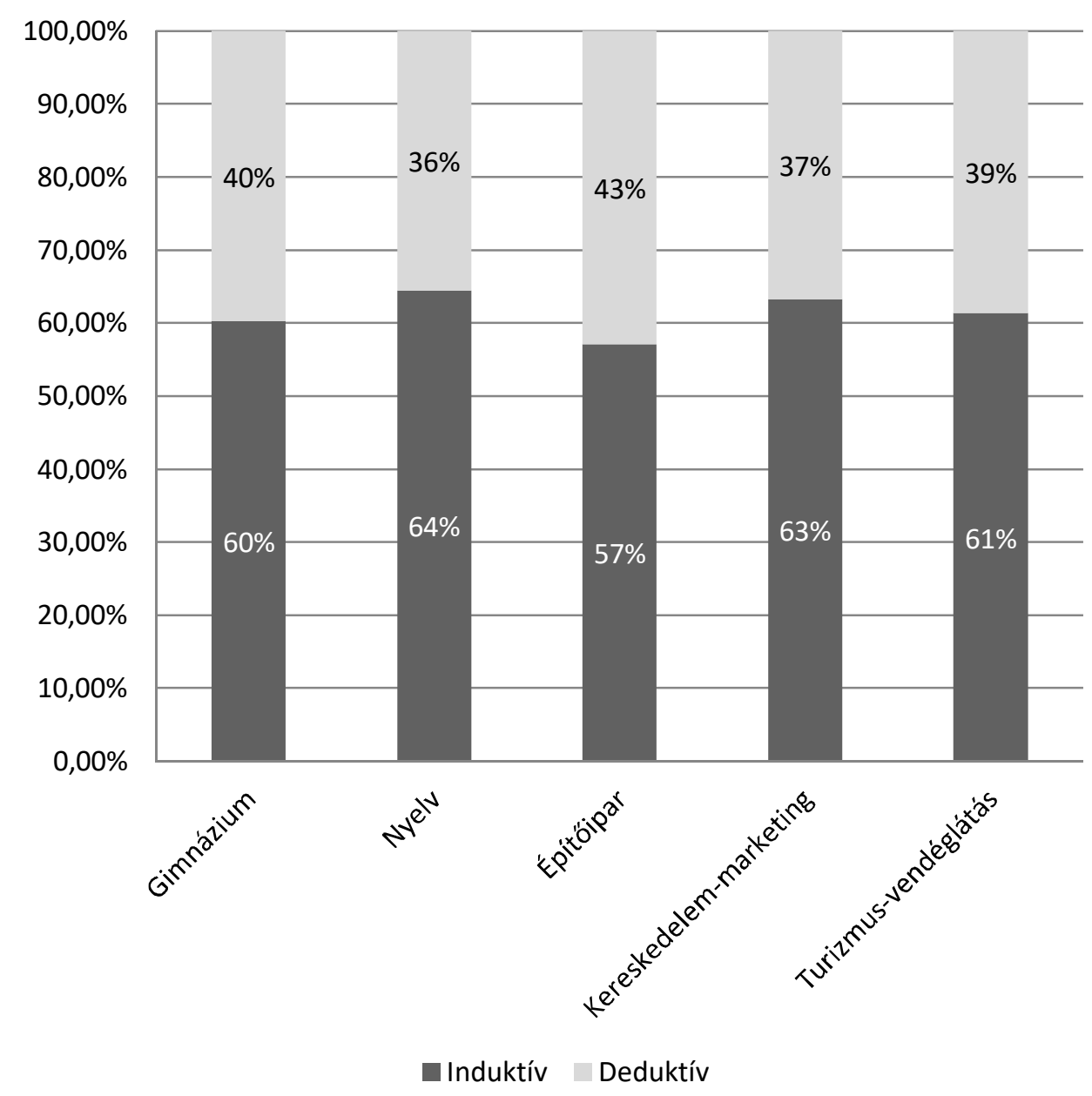

Forrás: Saját szerkesztés

6. ábra: A válaszadók szakok szerinti megoszlása

A százalékos megoszlás szinte hasonló eredményt mutat minden szakiránynál. Nagy különbséget nem tudunk felfedezni. A gimnáziumi tanulóknál, illetve a nyelvnél is az induktív van többségben, azaz $60 \%$ és $64 \%$, míg a deduktív csoportba $40 \%$ és $36 \%$ tartozik. A gyakorlatiorientált szakmáknál meglepően alacsonyabb az építőipar megoszlása, itt az induktív-deduktív arány 57\% és 43\%. A legnagyobb különbség a kereskedelem-marketing szaknál van, itt a válaszadók 63\%-a tartozik az induktív csoportba, míg 37\% a deduktív csoportba. A turizmus-vendéglátás szakirány hasonló eredményt mutat, mint a gimnáziumi tanulóké, azaz 61\%-ot-az induktív és 39\%ot a deduktív tanulási stílus jellemzi.

A következő feltételezés, hogy az induktív-deduktív megoszlás évfolyamonként eltérő lehet. Ennek megoszlását a 7. ábrában szemléltetem. 


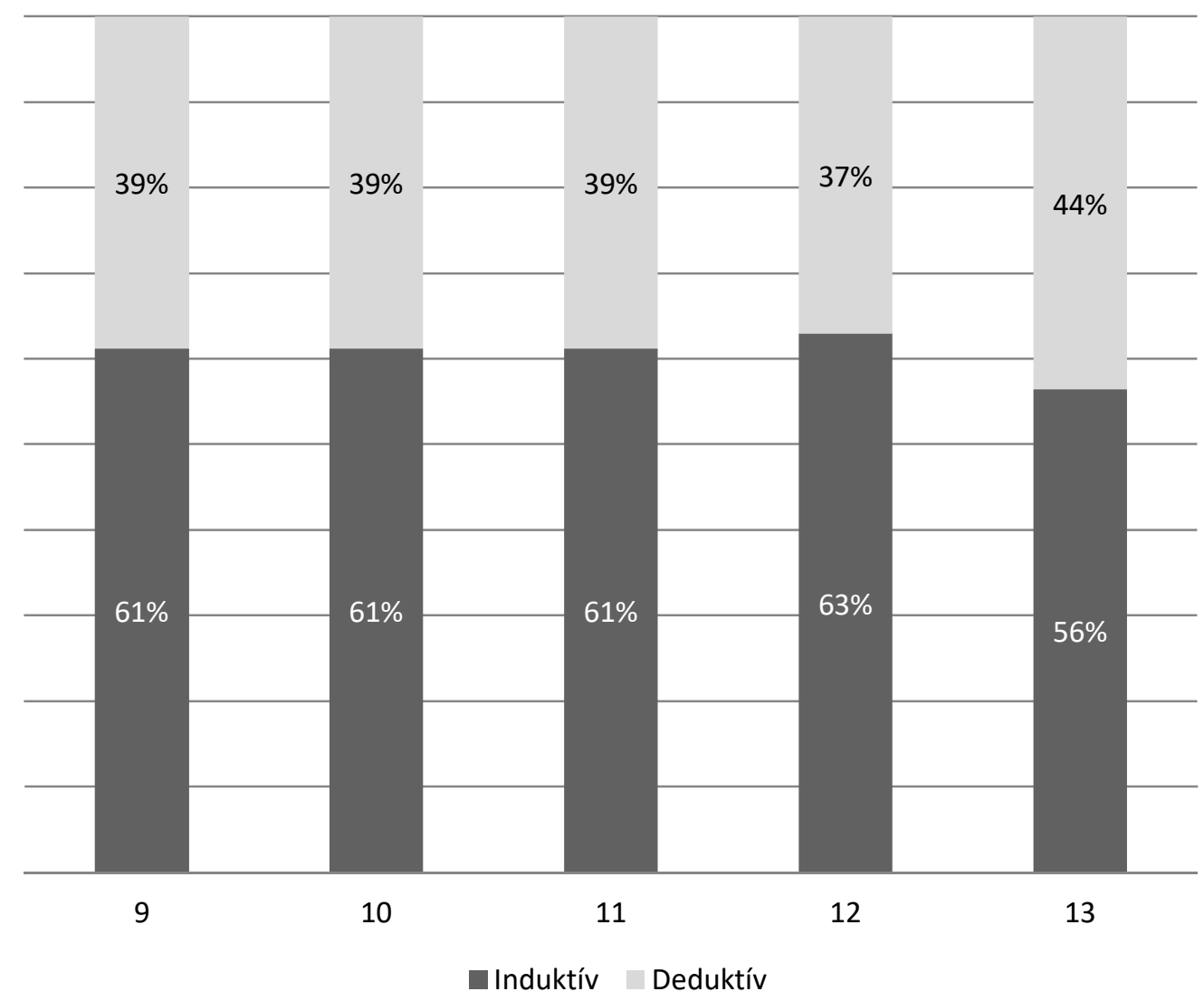

Forrás: Saját szerkesztés

7. ábra: A válaszadók évfolyamonkénti megoszlása

A tendencia 9-12. évfolyamig az induktív irányába nő. Majd 13. osztályba, azaz ötödéven vagy az öt éves képzés utolsó évében láthatjuk azt, hogy nő a deduktív irányba a százalékos megoszlás. A 9. évfolyamnál 61\% tartozik az induktív csoportba, míg 39\% a deduktív csoportba. A 10. évfolyamnál hasonló a helyzet, itt kéttized százalékkal nő csak, azaz 61\%-a induktív és 39\% deduktív. A 11. osztálynál megint nő az induktív irányba a megoszlás, itt az arány $61 \%$ induktív és $39 \%$ deduktív. A 12. évfolyam arányai a következőképp alakulnak: 63\%-a induktív és $37 \%$.a deduktív. Mint már említettem a 13. évfolyamosoknál kicsit csökkent az induktív száma, mégpedig 56\%-ra, de így nőtt a deduktív aránya, 44\%-ra.

Ez azt jelenti, hogy a diákokat teljesen elviszi a tanulás arra, hogy a definíciókat, fogalmakat tanulják meg, nem pedig a saját ismereteiket bővítsék. Leginkább jegyzetelni fognak, magolni, nem pedig a gyakorlati tudást erősítik. Ezáltal ha kikerülnek a munkaerőpiacra, kevésbé fognak tudni megfelelően teljesíteni. 


\section{Konklúziók, javaslatok}

„A tanuló ne gondolatokat, hanem gondolkozni tanuljon.”

/Immanuel Kant/

Célom az volt, hogy képet kapjak arról, hogy a középiskolás tanulók milyen arányban tartoznak az egyes tanulási csoportokba, hiszen a tananyagot ennek alapján könnyebben fel lehet építeni. Ezen kívül az egyes csoportok jellemzőinél láthatjuk, hogy milyen eszközöket kell alkalmaznunk a hatékony tanulás érdekében, valamint a tanuló hogyan tud otthon könnyebben tanulni.

Kiderült, hogy a válaszadók nagy része a vizuális csoportba tartozik, tehát fontosak a képek a tanórán. Ha a táblára is írunk, próbáljuk meg színessé tenni, színes krétákat használni, habár a táblára való írásnál is elveszhet a módszertani fejlesztés, így ennél jobb lehet a projektor használata. A vetítésnél próbáljuk meg a jegyzetelésre tanítani a gyerekeket, ne egész mondatokat írjanak le, mert a rövid vázlatot a vizuális típus hamarabb megjegyzi.

Az információ felvételénél a diákok többsége a konkrét típusba tartozik. Itt az a jellemző, hogy a begyakorolt feladattípust meg fogja tudni oldani a diák. Ám ami ismeretlen, fantázia hiányában nem tud boldogulni vele. Célszerü itt például, hogy dolgozatnál vagy feleletnél olyan kérdést tegyünk fel és úgy, ahogy órán elhangzott. Ha szeretnénk öket logikus gondolkodásra késztetni, lassan és türelmesen tegyük ezt.

A következő vizsgálat eredménye, hogy a kitöltők nagyobb része aktív csoportba tartozik. A csoportra jellemző a nyitottság, tehát merjünk új dolgokat megismertetni velük. Egy új játékos feladattal biztos fogunk tudni nekik kedvezni, amit egyrészt élvezni fogják, mert játszanak, de újat is tanulnak, méghozzá nem könyvből.

Az információ megértése, mint például egy új ismeretet hogyan dolgoz fel, közel megegyezett, de döntő többségben az analitikusok vannak, akik a kis tananyagokat szeretik, mert az egészet nem látják át. Viszont a globális tanulási stílusba tartozók a fejezetet egészként kezelik, a kiegészítő anyagokat is megnézik. Tehát a csoportnak a feladatokat kis részekre bontsuk le, hogy könnyebben tudjon tanulni számára átláthatóbb lesz.

Így mindezek függvényében azt kaptuk következtetésnek, hogy a diákok többsége az induktív csoportba tartozik. Jobban szeretnek leülni és megtanulni a definíciókat, minthogy a korábbi tapasztalataira hagyatkozzon és esetleg saját szavaival fogalmazza meg azt.

A szülök iskolai végzettsége, valamint az évfolyam nem befolyásolja azt, hogy a csoport induktív vagy deduktív lesz. Átlagban $60 \%$-a $( \pm 3 \%)$ tartozik az induktív csoportba, azaz mindenki az inkább „,magolós” típusba tartozik, mintsem a már meglévő tudásába próbálná beilleszteni az új információt. Véleményem szerint ennek az az oka, hogy nem tudják elmélyíteni az eddigi tudást olyan szinten, hogy utána át tudják látni az összefüggéseket.

Úgy gondolom, hogy azért is kaphattunk ilyen eredményeket, mert a magyar közoktatás nagyon merev és lexikális tudást kapnak a diákok. Nagyon kevés a gyakorlati rész, amikor a tanuló látja az eredményét annak, amit készít, viszont a sok tananyag miatt a tanárnak is kevés lehetősége adódik az órán. Olyan szemléltetésre 
lenne szükség, amit a diák maga tapasztalhatna meg egy-egy órán, akár a mértékváltásnál konkrétan kimérni, hogy mennyi is a váltószám az egyes számok között. A szakmai tárgyaknál pedig rengeteg videó állna a tanár rendelkezésére, de órán nem lehetséges sokszor a vetítés, mert a technikai feltételek sem adottak és a tanmenet szerint pedig haladni kell.

Ma már égető probléma, hogy hogyan lehet a tanulók tanulástechnikáját fejleszteni, a tanulás iránti vágyukat ösztönözni. A tanulók az első nehézségek után feladják a tanulást, ezért minden lehetőséget és alternatívát meg kell ragadni, hogy a segítségükre legyünk.

Ezen kívül a javaslatom még az lenne, hogy a pedagógusok is kapjanak értesítést arról, hogy az adott tanuló milyen csoportba tartozik, hiszen az órát annak alapján könnyebben fel lehet építeni. A pedagógusoknak napra késznek kell lenniük és tanóráikat az új generációhoz kell igazítani. Esetlegesen olyan csoportokat létrehozni, akik egyformák, és nekik úgy megtartani, olyan módszerekkel az órát, ahogy a tanulási stílus megkívánja, hiszen így lehet sikeresen elsajátítani már órán a tananyag nagyobb részét. Természetesen ez azzal járna, hogy a pedagógusoknak képzést kellene erröl kapni, valamint az iskoláknak is minden teremre be kellene szereznie a megfelelö technikai feltételeket.

Továbbiakban ezt a felmérést érdemes lenne országos szintre kiterjeszteni, hogy egy teljesen reprezentatív felmérést tudjunk készíteni. Az ország egyes részein más anyagi körülmények között élnek a diákok. Meghatározó lehet a település is, ahol a tanuló felnevelkedett. Ezen kívül még alternatív iskolákra is ki lehetne terjeszteni és ott is megvizsgálni a kapott eredményeket, hogy ott is hasonló eredményeket kapnánk, vagy teljesen eltérő lenne.

\section{Összefoglalás} „Én azt hiszem, annál nincs nagyobb öröm, mint valakit megtanítani valamire, amit
nem tud, és nagyobb jótétemény sem."

/Móricz Zsigmond/

Összefoglalva a tanulmányt, igen hasznos felmérési eredmények születtek. A cél, hogy felismerjük, hogy az adott tanuló vagy csoport mely típusba tartozik, és ennek alapján felépíteni az órát. A leghatékonyabb az lenne, ha mindkét típusú csoport számára tudnánk a tanórát megtervezni, hiszen nincs lehetőség arra, hogy az osztályokat a tanulási stílus szerint különböztessük meg és osszuk csoportokra.

De ha mindezt meg is valósítanánk, akkor az azzal is járna, hogy minden iskolának jóval nagyobb technikai felszereltséggel kellene rendelkeznie, mint most. A képek mellett az auditív típusnak hangfájlokat tudnánk mutatni, amivel viszont ez a csoport tanulna hatékonyan. Tehát máris találtunk egy megoldást arra, hogy mindkét csoportot le tudjuk kötni órán.

Viszont ami a legfontosabb, hogy a tanító pedagógusokat is fejleszteni kellene. Merjék használni az IKT eszközöket. Ebben főként az idősebb kollégáknak kellene segíteni és esetleg eleinte valamiféle ingyenes képzést biztosítani a szabad idejük 
terhére. De egy pozitív marketinggel úgy gondolom, meg lehetne öket fogni, mert ez nekik is nagy segítség lenne az órán. Kevesebb magyarázással, valamint videók, képek, hanganyagok segítségével sikeresebb diákokat nevelhetünk és kerülhetnek ki az iskolából. Ez mind a pedagógusnak, mint az iskolának, de legfóképpen a diáknak és a szülőknek lenne kedvező. Továbbá nem elhanyagolható a társadalomra gyakorolt hosszú távú hatása sem.

Eddig az iskola és a pedagógusok szemszögéből vontam le a konklúziót és fogalmaztam meg javaslatot. Ugyanakkor az egyik legfontosabb lenne a másik oldallal is ugyanezt megértetni, azaz a szülővel és a gyerekkel. A tanulónak segíteni kell megtalálni a maga tanulási stílusát. Ha tudja, hogy ő képek alapján tanul jobban, mutassunk neki videókat, vagy olyan applikációt, ahol képileg történik a memorizálás. Ha pedig verbális, akkor azzal tudjuk segíteni, hogy esetleg a tananyagot mondja fel egy hangrögzítöre és azt hallgassa. Onnan fog könnyebben tanulni. Így a nehezebbnek tünő tárgyakat is sikeresebben fogja teljesíteni. Kevésbé lesznek rossz jegyei és sikere lesz az iskolában.

A szemléletváltás nemcsak a pedagógusok részéről, de a tananyag összeállításában is szükséges.

\section{Felhasznált irodalom}

1. BALOGH L. (1993): Tanulási stratégiák és stílusok, a fejlesztés pszichológiai alapjai, Debrecen, KLTE.

2. BALOGH L. (1995): Tanulási stratégiák és stílusok, a fejlesztés pszichológiai alapjai.

file://G:/BGE/TDK/Tanulasi_strategiak_es_stilusok4302410657599585100.pdf

Letöltés: 2018.08.27.

3. BERNÁTH L., N. KOLLÁR K., NÉMETH L. (2015): A tanulási stílus mérése, http://www.eltereader.hu/media/2015/11/IP36 READER1.pdf

Letöltés: 2018.09.28.

4. BODNÁR É., SASS J. (2016): Hogyan tud reagálni a felsőoktatás a hallgatóknál tapasztalható egyéni különbségekre, http://mellearn.hu/wp-content/uploads/2016/10/Dr.-Bodn\%C3\%A1r\%C3\%89va.pdf

Letöltés: 2019.11.06.

5. DINYÁNÉ SZ. M. (2013): Tanulásmódszertan, http://semmelweis.hu/dei/files/2013/11/Tanul\%C3\%A1sm\%C3\%B3dszertan1.p df, Letöltés: 2018.08.25.

6. GINNIS P. (2007): Tanitási és tanulási receptkönyv, Fordította: Kovács Lajos (2008), Pécs, Alexandra Kiadó

7. KATHYNÉ M. A. (2013): Tanulási stílus, stratégia, módszerek és motiváció. http://rmpsz.ro/uploaded/tiny/files/magiszter/2013/nyar/5.pdf

Letöltés: 2018.08.27.

8. KNAUSZ I. (2001: 5): A tanitás mestersége, (Egyetemi jegyzet) http://mek.oszk.hu/01800/01817/01817.pdf Letöltés: 2018.08.25. 
9. MAKÓ F. (2015): Tanulásmódszertan, https://www.tankonyvtar.hu/hu/tartalom/tamop412b2/20130002 tanulasmodszertan/tananyag/JEGYZET-071.3. Azz onallo tanulas szemel.html Letöltés: 2018.08.27.

10. MCCRINDLE R. (2012): Generations Defined Sociologically, https://mccrindle.com.au/wp-content/uploads/2018/03/Generations-DefinedSociologically.pdf Letöltés: 2019.11.06.

11. METCALF, L. (2008): Megoldásközpontú tanitás, Pécs, Alexandra Kiadó

12. MEZÖ F. (2002): A tanulás stratégiája, Debrecen, Pedellus Kiadó.

13. OROSZLÁNY P. (1997): Könyv a tanulásról, Budapest, Független Ped. Int. Tankönyvcentrum.

14. OROSZLÁNY P. (2004): Tanulásmódszertan, Budapest, Metódus-tan Bt. Kiadó.

15. VÖRÖSMARTY Gy. (2016): Beszerzési csoportok kezelése, file://G:/Publik\%C3\%A11\%C3\%A1s/VT2017n1p41.pdf Letöltés: 2019.11.06. 